\title{
209 MRI cardiac catheter assessment of total and differential pulmonary vascular resistance in the context of single ventricle physiology
}

\author{
Aaron J Bell*, Gerald Greil, Philipp Beerbaum, Tobias Shaeffter and \\ Reza Razavi
}

Address: Kings Collge London, London, UK

* Corresponding author

from I th Annual SCMR Scientific Sessions

Los Angeles, CA, USA. I-3 February 2008

Published: 22 October 2008

Journal of Cardiovascular Magnetic Resonance 2008, I0(SuppI I):A70 doi:I0.II86/I532-429X-I0-SI-A70

This abstract is available from: http://jcmr-online.com/content/I0/SI/A70

(c) 2008 Bell et al; licensee BioMed Central Ltd.

\section{Introduction}

In patients with complex cyanotic heart disease, pulmonary blood flow may be derived from more than one source, making assessment of pulmonary vascular resistance (PVR) difficult by conventional methods. Phase contrast MRI (PC-MRI) combined with invasive cardiac catheterization enables accurate measurement of the PVR. We demonstrate the application of MRI catheter in this patient group.

\section{Hypothesis}

MRI Cardiac catheter can assess the PVR in these patients, including those with multiple sources of pulmonary blood flow.

\section{Methods}

MRI cardiac catheterisation was performed in a combined XMR suite with a Philips 1.5 T Intera Achieva MR scanner and a single plane cardiac X-Ray unit. All patients underwent MRI cardiac catheter under general anaesthesia and were ventilated to normocarbia. Simultaneous pressure measurements were obtained with PC-MRI according to the vascular anatomy. Differential pulmonary blood flow was measured distal to all sources of blood flow. For those patients with multiple sources of blood flow, PVR was calculated by the equation: $1 / \mathrm{PVR}_{\text {total }}=1 / \mathrm{PVR}_{\text {left }}+1 / \mathrm{PVR}_{\text {right }}$. Data is expressed as mean ( \pm standard deviation), means are compared with a 2-tailed t-test.

\section{Results}

Twenty MRI cardiac catheters were performed in 18 patients with complex cyanotic disease, median age 3.63 years $(0.5$ to 41.7$)$. For all patients, the mean PVR was 2.95 WU. $\mathrm{m}^{2}( \pm 1.41)$. Differential PVR was measured in 11 patients, the mean $\mathrm{PVR}_{\text {right }}$ was $6.70( \pm 2.01)$ WU.m ${ }^{2}$ and was significantly elevated compared to the mean PVRleft of $3.49( \pm 1.12)$ WU. $\mathrm{m}^{2}(\mathrm{p}=0.002)$. Seven of these patients had multiple sources of pulmonary blood flow (Table 1). Seventeen patients were being investigated for suitability for progression to the next stage of cavo-pulmonary connection, 11 patients were suitable and 6 were unsuitable. The mean PVR or those suitable was 2.35 WU. $\mathrm{m}^{2}( \pm 0.58)$ compared to 4.54 WU. $\mathrm{m}^{2}( \pm 1.57), \mathrm{p}=$ 0.017 , for those who were unsuitable for further cavo-pulmonary palliation. The remaining three patients underwent assessment for complications related to the fontan circuit, the mean PVR was 2.14 in this group.

\section{Conclusion}

In patients with a single ventricle physiology, the PVR needs to be low in order to proceed with palliation by means of a cavo-pulmonary connection. This can be determined by MRI cardiac catheter. Additionally, this technique offers the advantage of being able to measure the differential pulmonary vascular resistance, even in the context of multiple sources of pulmonary blood flow. We 
Table I: Patients with multiple sources of pulmonary blood flow. MRI Cardiac Catheter allows for the measurement of pulmonary vascular resistance in patients with complex congenital heart disease. Differential pulmonary vascular resistance can be measured when there are multiple sources of pulmonary blood flow.

\begin{tabular}{|c|c|c|c|c|c|c|c|c|}
\hline & \multirow[t]{2}{*}{ Age (years) } & \multirow[t]{2}{*}{ Diagnosis } & \multirow[t]{2}{*}{ Procedures } & \multirow{2}{*}{$\begin{array}{l}\text { Sources of } \\
\text { pulmonary blood } \\
\text { flow }\end{array}$} & \multicolumn{3}{|c|}{ PVR (WU.m²) } & \multirow[t]{2}{*}{ Outcome } \\
\hline & & & & & Right & Left & Total & \\
\hline 1 & 3.1 & $\begin{array}{l}\text { Right atrial isomerism Complete } \\
\text { atrioventricular septal defect Double } \\
\text { outlet right ventricle Recurrent } \\
\text { chylothoraces }\end{array}$ & TCPC & SVC and IVC & 4.4 & 3.6 & 2.0 & $\begin{array}{l}\text { Conservative } \\
\text { management of } \\
\text { chylothoarces }\end{array}$ \\
\hline 2 & 3.0 & $\begin{array}{l}\text { Hypoplastic Left Heart Syndrome } \\
\text { Recurrent ascites }\end{array}$ & TCPC & SVC and IVC & 6.8 & 5.0 & 2.9 & $\begin{array}{l}\text { Recreation of atrial } \\
\text { fenestration }\end{array}$ \\
\hline 3 & 12.5 & $\begin{array}{l}\text { Double inlet left ventricle } \\
\text { Transposition Great Arteries } \\
\text { Hypoplastic right ventricle }\end{array}$ & SCPC & SVC MPA & 3.3 & 4.3 & 1.9 & Proceed to TCPC \\
\hline 4 & 11.5 & $\begin{array}{l}\text { Right atrial isomerism Atrioventricular } \\
\text { Septal Defect Pulmonary atresia } \\
\text { Protein losing enteropathy }\end{array}$ & TCPC & SVC and IVC & 9.3 & 1.9 & 1.6 & $\begin{array}{l}\text { Medical treatment of } \\
\text { protein losing } \\
\text { enteropathy }\end{array}$ \\
\hline 5 & 13.7 & $\begin{array}{l}\text { Mitral valve dysplasia Hypoplastic left } \\
\text { ventricle Double outlet right ventricle }\end{array}$ & PA Band & MPA Right MBTS & 6.9 & 2.7 & 1.9 & Proceed to SCPC \\
\hline 6 & 1.47 & $\begin{array}{l}\text { Pulmonary atresia intact ventricular } \\
\text { septum }\end{array}$ & $\begin{array}{l}\text { Pulmonary } \\
\text { valvotomy and } \\
\text { ductal stent }\end{array}$ & MPA Arterial duct & 6.0 & 3.3 & 2.1 & Proceed to SCPC \\
\hline 7 & 41.7 & $\begin{array}{l}\text { Situs inversus Double inlet left } \\
\text { ventricle Atrioventricular septal } \\
\text { defect Pulmonary stenosis }\end{array}$ & $\begin{array}{l}\text { Right MBTS } \\
\text { Pulmonary } \\
\text { valvotomy }\end{array}$ & MPA Right MBTS & 5.5 & 3.2 & 2.0 & $\begin{array}{l}\text { Suitable for SCPC, } \\
\text { patient elected for } \\
\text { conservative } \\
\text { management }\end{array}$ \\
\hline
\end{tabular}

Abbreviations: TCPC - Total cavo-pulmonary connection, SVC - superior vena cava, IVC - inferior vena cava, MPA - Main Pulmonary Artery, SCPC - Superior cavo-pulmonary connection, MBTS - Modified Blalock Taussig shunt.

have found a difference in the mean PVR between the right and left lungs, which merits further investigation.

Publish with Biomed Central and every scientist can read your work free of charge

"BioMed Central will be the most significant development for disseminating the results of biomedical research in our lifetime. "

Sir Paul Nurse, Cancer Research UK

Your research papers will be:

- available free of charge to the entire biomedical community

- peer reviewed and published immediately upon acceptance

- cited in PubMed and archived on PubMed Central

- yours - you keep the copyright

Submit your manuscript here:

http://www.biomedcentral.com/info/publishing_adv.asp
BioMedcentral 